\title{
Introduction: Symposium on history and Austrian economics
}

\author{
Michael Douma ${ }^{1}$
}

Published online: 27 June 2017

C Springer Science+Business Media New York 2017

The articles in this symposium point to three approaches to the study of the history of Austrian Economics. We may understand these as studying the context of the early development and the reception of ideas. Combined, the articles in this symposium reinforce the picture of Austrian economics, not as an alternative way of doing economics, but instead an alternative broad social science and philosophy. This perspective contributes to a changing understanding of Austrian economics, away from the narrow study of economic processes, and towards social process of change and stability more broadly. The three papers all point to the broader aspects of the research program of the Austrians, concerned with the study of history, the role of (historical) institutions, and the way in which social change was conceptualized.

The first article, by Leo Krasnozohn and Mykola Bunyk, provides the first detailed studied of Ludwig von Mises' first book, a generally forgotten work of history on peasants in Galicia, then a part of the Austro-Hungarian Empire. The authors argue that Mises's first book, written as university thesis in 1902, demonstrates that the young Mises was not following in the footsteps of the German Historical School, as previous scholars have assumed. The authors point to the influence of Mises's historical training on his developing views on economics. For example, this early book shows Mises's skepticism for bureaucracy, his antagonism towards materialist explanations of historical change, and his appreciation for the subjective nature of historical phenomenon.

In the second article, Erwin Dekker argues that Schumpeter's original version of 'The Theory of Economic Development' is best read and interpreted alongside the avant-garde manifestoes of the pre-WWI period. As such it broke with the Habsburg tradition of conservative gradualism and schlamperei, and sought to embrace the new. Central to Schumpeter's view of entrepreneurship is that there is a Man of Action (Mann der Tat) who brings about change. While others in the Austrian

Michael Douma

michaeljdouma@gmail.com

1 Georgetown Institute for the Study of Markets and Ethics, McDonough School of Business, Georgetown University, P.O. Box 48, Bloomery, WV 26817, USA 
tradition viewed social change as an organic development, Schumpeter embraced, in Dekker's words "a far more revolutionary concept of social change, which could be bought about by strong individuals, and which suggested that economists could be agents of such change. Dekker's focus on the cultural context of ideas in Austrian economics is important in that it shows us the dynamic range of possibilities and influences on its development.

The third article, from Michael Douma, is a study of the reception of Ludwig von Mises's Theory and History (1957) among professional historians. Focusing mainly on the Anglo-American world, where the book was most heavily reviewed and criticized, Douma argues that there was a genuine conceptual divide between Mises and his audience of professional historians which prevented a full understanding of his work. While a few historians dismissed Mises on ideological grounds, a more likely reason for the failure of this book to gain ground in the philosophy of history was that it was written in English, for an American audience, but dealt with questions that had been asked primarily only in Germany nearly a half-century before. Douma believes that this work should have made a real impact among historians, but that it was overshadowed by Popper's The Poverty of Historicism (1957) which had some similar aims.

A common theme in these articles is social reform. Mises (1902) was a part of the bigger project led by the younger German Historical School to demonstrate advantages of a state-initiated social reform. Social reform was a central topic for the younger German historicists because of the 1873 Economic Crisis but, mainly, because of the growing labor movement in Europe. The German Historicist and other classical liberals were greatly alarmed by the advancement of Marxism and Socialism. Thought Historicists and Marxists were influenced by Hegel, the former rejected the dialectic construction of history propagated by the latter. So Historicists decided to unite their scholarly efforts in the struggle for the study of social change which would take into consideration the needs of the workers/farmers, so-called proletariat. In his work, however, Mises failed to reinforce the view that his predecessors intended for him to present. Schumpeter (1912), meanwhile, raised the idea of social change to the next level of the gradualist/revolutionary debate or what we call today, the gradual vs. shock therapy reform. In the Theory and History (1957), Mises continued the debate on social reform. Like in Human Action, Mises compares economics to history in several chapters by discussing a role of economics as a science of human action and attacking Hegel with Marx. In modern Austrian Economics.

The authors hope for increased interest in historical topics of the Austrian school, and are confident that such researches will contribute to a better understanding of the school's ideas. 